\title{
ANTIBIOTIC RESIDUES IN FOOD CHAINS; IMPACT ON THE ENVIRONMENT AND HUMAN HEALTH: A REVIEW
}

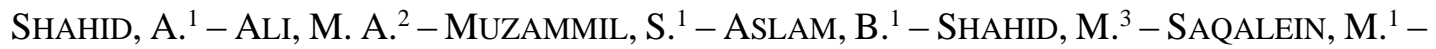 \\ AKASH, M. S. H. ${ }^{4}-$ Almatroudi, A. ${ }^{5}-$ AllemaIlEM, K. S. ${ }^{5}-$ KHURSHID, M..$^{1 *}$ \\ ${ }^{1}$ Department of Microbiology, Government College University, Faisalabad, Pakistan \\ ${ }^{2}$ School of Biological Sciences, University of the Punjab, Lahore, Pakistan \\ ${ }^{3}$ Department of Bioinformatics and Biotechnology, Government College University, Faisalabad, \\ Pakistan \\ ${ }^{4}$ Department of Pharmaceutical Chemistry, Government College University, Faisalabad, \\ Pakistan \\ ${ }^{5}$ Department of Medical Laboratories, College of Applied Medical Sciences, Qassim University, \\ Buraydah, Saudi Arabia \\ *Corresponding author \\ e-mail:mohsin.mic@gmail.com; mohsinkhurshid@gcuf.edu.pk; phone:+92-333-430-1513
}

\author{
(Received $2^{\text {nd }}$ May 2021; accepted 29 Jul 2021)
}

\begin{abstract}
The antibiotic residues in the food chain are a growing public health concern due to their involvement in the development of antimicrobial resistance, mutagenicity, carcinogenicity, hypersensitivity, bone marrow suppression, and disruption of gut microbiota. The indiscriminate use of antibiotics for the treatment of diseases and improved animal production results in the deposition of these residues in milk, eggs, and meat although their use is not highlighted for the foods consumed by human beings. Moreover, the antibiotics consumed in the clinical settings and animal production are excreted into the environment at a large scale which may adversely disturb the terrestrial and aquatic ecosystems. The matter can become more momentous soon because the production of food animals at an industrial scale will significantly increase the use of antimicrobials. The problem caused by these antibiotic residues in the food chain is two-fold; the direct toxicity to humans and the possibility of the emergence of resistant bacterial strains ultimately leading to the failure of antibiotic therapy. Present article critically analyses the factors contributing to the presence of antibiotic residues in the food chain and their implications and perilous impact on consumers and proposes the possible ways to reduce the antimicrobial residues in the food.
\end{abstract}

Keywords: antimicrobial residues, microbiota, antimicrobial resistance, ecosystem, maximum residue limits

\section{Introduction}

Natural, synthetic, as well as semisynthetic drugs which can kill or inhibit the growth of microorganisms, can be termed antibiotics (Catteau et al., 2018). Antibiotics are the most effective group of drugs to treat bacterial infections in both humans as well as in animals by acting specifically on their targets (Figure 1). Following the discovery of penicillin in 1928, thousands of antibiotics were produced for animals, plants, and human use. Initially, these antibiotics were employed in clinical and veterinary settings only for the therapeutic management of certain infections; later, the drugs were also used as growth promoters especially in livestock and poultry industries. Antibiotic usage was prohibited in Europe in 2006, however, their use in livestock, poultry, and agriculture 
sectors is still common in many parts of the world including China and India (Gonzalez Ronquillo and Angeles Hernandez, 2017; Cowieson and Kluenter, 2019).

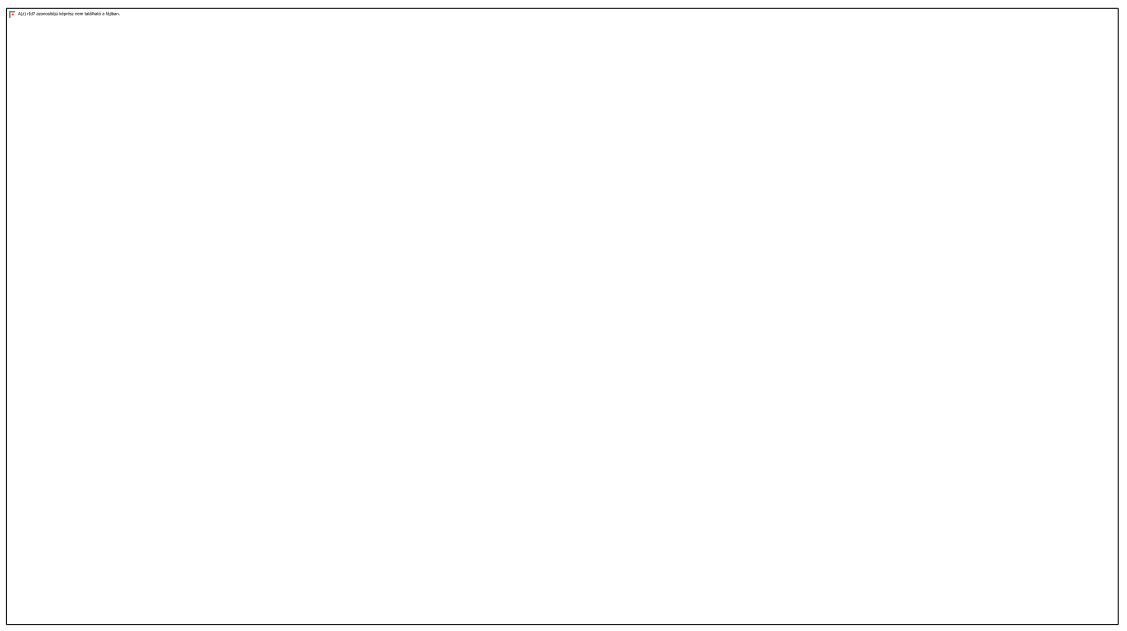

Figure 1. Various groups of antibiotics

It is estimated that the global usage of antibiotics was around 63,151 tons in 2010 for food animals and aquaculture. Additionally, it is anticipated that the amount will further increase by $67 \%$ until 2030 with the highest consumption in India, Brazil, Russia, and South Africa (Van Boeckel et al., 2015). This irrational use of antibiotics in agriculture, humans, and animals resulted in the accumulation of antibiotics residues in the natural ecosystem and environment that can pose harmful effects such as the development of antimicrobial resistance. Many other public health concerns have been raised in regard to the antibiotic residues in the food chain and environment. For example, the ingestion of antibiotic residues could alter the human microbiota and promote resistance among the human normal bacterial flora. Moreover, the unwarranted use of antibiotics leads to their accumulation in the tissues of the food animals as residues and which ultimately become part of the food chain. Therefore their use is prohibited by the health, as well as food regulatory authorities (Landers et al., 2012).

The present study aimed to provide a comprehensive view of health risks associated with antibiotic residues in the food chain and environment including the effects on the emergence of antibiotic-resistant bacteria and to discourse the information gap and provide recommendations to reduce the antibiotic residue in the food chain to avoid the potential hazards to human, animal and environmental health. Here we summarize the studies on the relationship between the use of antimicrobials for the growth promotion in food-producing animals and the development of resistance in bacteria. Further, we focused on the presence and detection method of various antibiotics in foods of especially of animal origin. Moreover, the sources of antibiotics in foods from different origins are summarized. Further, the impact of antibiotic residues on the consumers is summarized.

\section{Antimicrobial residues}

Synthetic and semisynthetic antimicrobials are used in veterinary and human medicine for the treatment and control of diseases and can be administered topically, orally, and parenterally. Furthermore, they play an important role in promoting the growth of food 
animals (Barton, 2000). Antimicrobials can deposit in tissues of the body as residues and it takes some time for residues to be excreted or metabolized. The amount of these residues can be higher especially when these animals are consumed by the humans during their medication or soon after the medication withdrawal (Tollefson and Miller, 2000). Antibiotic residues can adversely affect human health by various processes such as damaging effects on the organs, antibiotic-resistant genes, and bacteria, direct toxicity to consumers (Kirchhelle, 2018). Several drugs such as nitrofurazone, ipronidazole, fluoroquinolones, chloramphenicol, furazolidone, and dimetridazole are illegal to use in food-producing animals. Antimicrobial residues are used therapeutically as well as prophylactically to promote growth and control diseases. The approved drugs for veterinary use have legally approved maximum residue limits (MRLs) for the parent drugs or their metabolites in the food products from the treated animals through assessment of safe concentration for consumers (Okocha et al., 2018).

\section{Sources of antibiotics in food}

The studies have suggested that antibiotics contaminate all kinds of human food products such as vegetables, livestock, aquatic products, and poultry products i.e. eggs, meat, and milk (Van Boeckel et al., 2015). Furthermore, it is considered that antibiotic residues can accumulate in aquatic products as these drug residues have been reported from various aquatic environments (Liu et al., 2017). The antibiotics and antibiotics residues being used as organic fertilizers in manure become part of vegetables (Azanu et al., 2016). Consequently, there are two main sources of antibiotic residues in food. Firstly, antibiotics are used for growth promotion as well as control of disease and to improve the efficacy of food in humans. Secondly the accumulation of these drug residues among the food animals living in an environment contaminated with antibiotics (Manyi-Loh et al., 2018). The sources and pathways of antibiotic residues in the food chain have been shown in Figure 2.

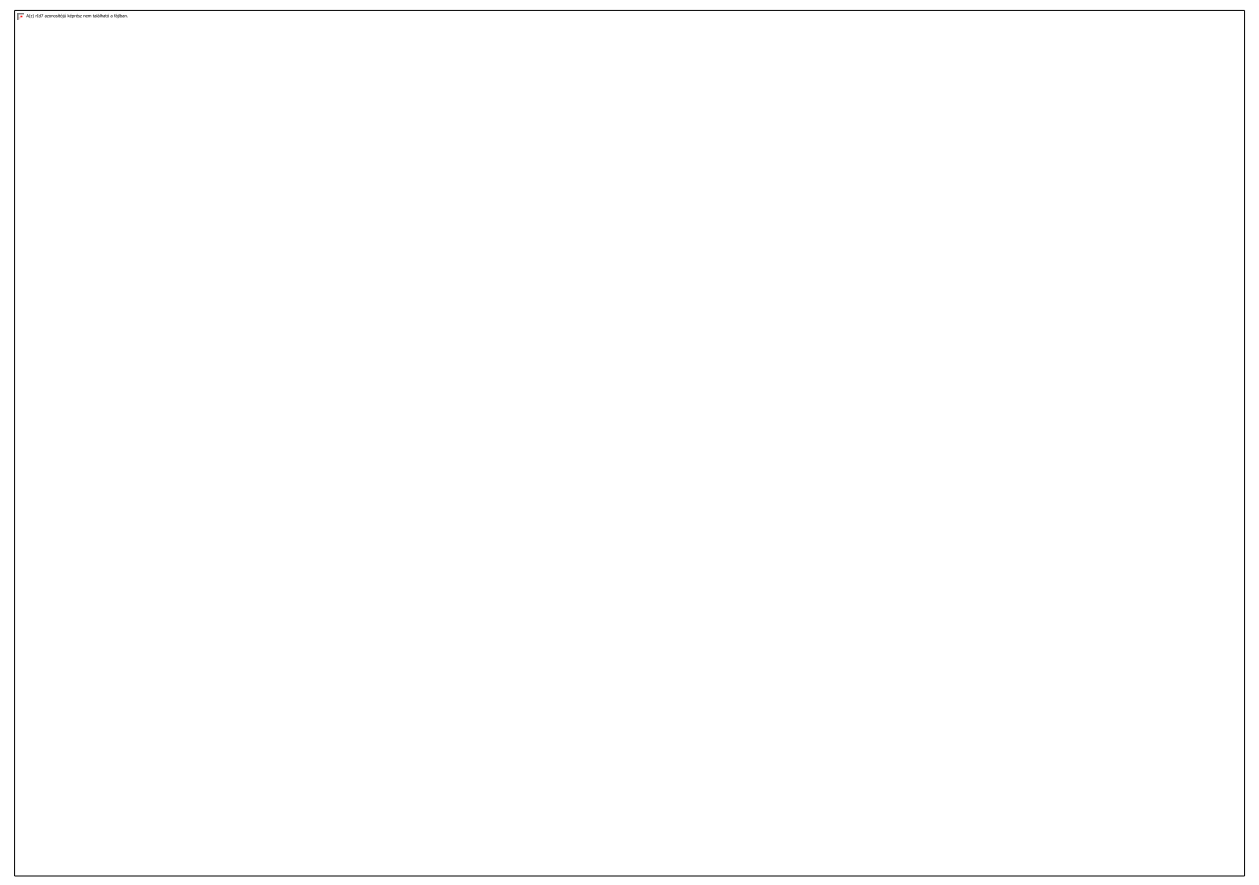

Figure 2. Sources and pathways of antibiotic residues in the food chain 


\section{Antibiotics residues in food}

Antibiotic residues accumulate in the blood as well as in other tissues, after administration of high concentrations of antibiotics however the use of non-medicated fodder in animals eradicates these residues from the blood as well as tissues of these animals. The high concentration of antibiotics administered to animals through injection or animal-derived feed as well as due to storage, water, and transportation during processing may result in the contamination of animal-origin foods (Nisha, 2008). Furthermore, feces can also contaminate food through fecal recycling, particularly vegetables are contaminated as feces are being used as a fertilizer (Phillips et al., 2004; Darwish et al., 2013). Antibiotics are widely used in fish farming and antibiotic residues are accumulated within human body systems following the use of contaminated fish that can adversely affect human health (Aarestrup et al., 1998). Reducing antibiotic residues in food heat treatment or cooking is important because very few raw products are used (Katz and Brady, 2000). The antibiotic residues accumulate in food products, for example, milk and meat, and several edible products although the low concentrations of antibiotic residues are considered as safe. In contrast, some antibiotics are harmful to human health, and their use is prohibited for example chloramphenicol. Milk is vital as well as beneficial food because it is a source of proteins in every age of people. Widespread use of antibiotics for treatment of mastitis in lactating cows and dry cow therapy leads towards accumulation of antibiotic residues in milk.

\section{Antibiotics residues in livestock and poultry products}

For poultry and livestock, antibiotics play a major role in the control and therapy of infectious diseases. Furthermore, antibiotics are commonly used as food additives to promote growth, improve food quality, and in maintenance of health in poultry and livestock industries. Consequently, antibiotic residues obtained from those animals are accumulated in food products and adversely affect human health. Furthermore, different kinds of food products are classified in poultry and livestock, for example, milk, eggs, chicken, pork, and beef, and three possible routes can contribute to the contamination of these products (1) through intrauterine and intramammary infusion or topical contact (2) when injected directly i.e. subcutaneous, intramuscular (IM) or intravenous (IV) for prophylaxis and treatment of disease (3) direct intake of water and feed in which antibiotics accumulate when used as an additive for growth promotion (Mitchell et al., 1998). Initially, antibiotic usage in the veterinary field was started for control and treatment of disease but nowadays these are widely used as additives for growth promotion. It has been observed that antibiotics are widely used as feed additives and fatteners for broilers to improve their growth and for better protection. Moreover, antibiotics also promote growth by decreasing various mechanisms such as toxin formation, nutrients waste, and the immune system's activity (Nisha, 2008). Antibiotics that are widely used for prophylaxis, growth promotion, and treatment in food animals are sulfamethoxazole, enrofloxacin, benzylpenicillin, tylosin, amoxicillin, trimethoprim, oxytetracycline, ampicillin, and streptopenicillin, while amikacin, neomycin, enrofloxacin, doxycycline, tetracycline, tilmicosin, and colistin sulfate are used for promotion of growth in the poultry (Chattopadhyay, 2014). A study has reported that virginiamycin; a food additive used for the livestock to enhance growth was found in the excreta of the treated animals. Additionally, the manure from the excreta serves as 
fertilizer owing to its soil binding capacity, it results in the contamination of water supplies (Tasho and Cho, 2016).

\section{Antibiotics residues in the biological systems}

The presence of narrow and broad-spectrum antibiotics in different environmental samples has been reported in various studies (Sarpong and Miller, 2015). The antibiotics are excreted by humans and animals which can contaminate the sewers and then to rivers as well as seas. For example, fluoroquinolone, sulfamethoxazole, and ofloxacin were detected from seawater of Hailing Island, Belgian harbors, and Laizhou Bay, respectively. Furthermore, sulfonamides and tetracycline were also detected in the discharge of wastewater treatment plants (Gao et al., 2012; Larsson, 2014). Several antibiotics are detected in hospital wastes, for example, beta-lactams, macrolides, lincomycin, fluoroquinolones, trimethoprim, sulfamethoxazole, and sulfonamides (Meena et al., 2015). It has been reported that ofloxacin, trimethoprim, sulfamethoxazole, and ciprofloxacin have been detected in municipal wastewater. Several antibiotics are used as feed additives in aquaculture industries. For example, sulfonamides, oxytetracycline, erythromycin, florfenicol, and sarafloxacin, are found in aqua samples. Five different compounds were detected in water samples in China i.e. ofloxacin, sulfonamides, norfloxacin, erythromycin, and amoxicillin with detection rates up to 65 to $7722 \mathrm{ng} / \mathrm{l}$. Oxytetracycline and tylosin were found rarely in wastewater while lincomycin, chlortetracycline, and sulfamethazine were detected frequently, furthermore to detect antibiotic residues from dairies effluents (Kumar et al., 2019).

Antibiotics and their residues are frequently excreted and contaminate natural environments. Different sources contribute to this pool of antibiotic residues, for example, animal husbandry, dairies, veterinaries, domestics, poultry, discharge of hospital waste, animal excreta, pharmaceutical plants, and municipal waste (Pruden et al., 2013; Obayiuwana et al., 2018). Several antibiotics are used in the agriculture industry to enhance fish farming, livestock growth, and beekeeping. The antibiotics and their metabolites are discharged particularly from the feces of the poultry animals and contaminate the natural environment (Hong et al., 2018). These residues and the metabolites pollute water and soil indirectly, for example, a polyether antibiotic i.e., the Monensin antibiotic used to promote the growth of animals in the dairy farms was found to spread to the natural resources (Mutiyar and Mittal, 2014). Although, the consumption of antibiotics is very low in plants than animals the residues were found in water used in agricultural land resulting in the contamination of the agricultural field (Piña et al., 2018). Few antibiotics have low molecular weight such as sulfonamides, aminoglycosides, nitrofurans, quinolones, macrolides, rifamycins, amphenicols, beta-lactams, tetracyclines, phosphonates, and lincosamides, therefore they dissolve readily in water bodies which results in longer persistence of antibiotics (Krzeminski et al., 2019). Antibiotics that are used in livestock can also contaminate the fields by manure and these antibiotic residues are absorbed in the soil and reach the groundwater (Ishikawa et al., 2018). Furthermore, when expired drugs are directly discarded in the sewage grid, these drugs can accumulate in landfills which increases contamination (Akici et al., 2018). 


\section{Antibiotics ecotoxicity and impact on bacteria}

The antibiotic residues are mixed with freshwater through soil erosion and rain (Mutiyar and Mittal, 2014). Antibiotics act on both target organisms (bacteria) as well as on nontarget organisms, for example on zooplankton, freshwater algae, and fish (Kummerer, 2009). The adverse effects of monensin on species richness have been reported (Hillis et al., 2007). Furthermore, fluoroquinolones are harmful to prokaryotes as compared to eukaryotes that are commonly present in hospital effluents and the long-term use of fluoroquinolone has shown harmful effects on human health as well as high genotoxicity (Brown et al., 2006; Ao et al., 2018). Antibiotics affect directly and indirectly the bacterial populations as their excessive use may lead to the development of resistance (Haller et al., 2002; Grenni et al., 2018). The presence of antibiotic residues in effluents results in contamination of seawater in the USA, Greece, China, Italy, Germany, Turkey, and Belgium. It has been reported that sulfamethoxazole, clarithromycin, roxithromycin, and erythromycin were detected from 153 samples of beach water from the Northern Adriatic Sea, San Francisco Bay, Baltic Sea, Dardanelles, Pacific Sea, Mediterranean, and Aegean Sea (Nodler et al., 2014). Based on biological, physical, and chemical properties antibiotics have different effects on organisms (Yelin and Kishony, 2018). The antibiotic, particularly those being used in the poultry and veterinary industry, increases the chance of survival of bacteria under antibiotic stress due to selection pressure which results in the evolution of multi-drug resistant (MDR) strains. These MDR strains are widely reported in the soil and aquatic milieus (Esiobu et al., 2002; Brown et al., 2006). It has been reported that $\beta$-lactams and aminoglycosides are less persistent in the environment as compared to fluoroquinolones as well as sulfonamides. In case of insufficient sunlight, the tetracyclines can persist and accumulate for a longer time. Furthermore, ciprofloxacin at 25,000 ng/l and norfloxacin at $5000 \mathrm{ng} / \mathrm{l}$ have shown to affect the DNA of genetically modified Salmonella typhimurium strains resulting in mutations (Ao et al., 2018).

\section{Use of antibiotics in foods}

Antibiotics are widely used in animals for many advantages covering carcass quality, promotion of growth, animal health, and cost-effective production (Van Boeckel et al., 2015). Antibiotics are the commonest drugs and are widely being used in animals as prophylactic and therapeutic agents for the management of infectious diseases. These antibiotics have played an important role in the prevention and cure of certain important infections caused by Escherichia coli, Campylobacter fetus, Enterococcus, Leptospira, Streptococcus suis, and Salmonella. Antibiotics enhance growth rate by altering the motility of the gut, by thinning the mucous layers in the gut, by decreasing waste nutrients, immune system activity, and formation of toxins, and by providing favorable conditions for beneficial intestinal microbes to destroy harmful bacteria (Darwish et al., 2013). The body weight of animals increases up to 4-5\% that receive antibiotics compared to those which are grown in the absence of these drugs (Witte, 1998). In veterinary medicine, several groups of antibiotics are used for these purposes, for example, lincosamide, aminoglycosides, ansamycins, and glycopeptides, $\beta$-lactams i.e. cephalosporin and penicillin, trimethoprim, Sulfonamides, quinolones, nitrofurans, tetracyclines (CháferPericás et al., 2010a). Few drugs or and their combinations are used as prophylaxis for different plant diseases for example streptomycin-oxytetracycline is used to control halo blight disease in beans and few other bacterial diseases in tomatoes, potatoes, cherries, tobacco, and peppers. Several drugs are used to inhibit trees from bacterial diseases such as 
aminoglycosides and tetracyclines. The studies have also reported the uptake of antibiotics by the vegetables such as corn, radish, carrot, and cabbage which were irrigated with the contaminated water (Kang et al., 2013; Bassil et al., 2013; Chowdhury et al., 2015).

\section{Detection of antibiotic residues}

Chromatographic and screening methods including the immunological and enzymatic methods are used to detect antibiotic residues. Microbiological methods such as microbial agar diffusion tests or inhibition of acid production by starter organisms were also used for the detection of antibiotic residues in food (Chowdhury et al., 2015). Antibiotic residues of sulphanilamide, streptomycin, ciprofloxacin, and tetracycline in meat samples were detected by three techniques i.e. HPLC, ELISA, and TLC. HPLC showed different antibiotic residues concentration i.e. $14.6 \%, 8.3 \%, 88.8 \%$ and $41.1 \%$ for tetracycline, ciprofloxacin, sulphanilamide and streptomycin respectively. ELISA detected that $25.3 \%$, $56 \%, 18 \%$, and $34 \%$ samples were positive for tetracycline, ciprofloxacin, sulphanilamide, and streptomycin, respectively, while TLC showed different concentrations i.e. $14.6 \%$ tetracycline, $21.4 \%$ ciprofloxacin, $92.5 \%$ sulphanilamide, and $29.4 \%$ streptomycin (Ramatla et al., 2017). In milk samples, the antibiotic residues were detected in 1960 for the very first time using the chromatographic technique. The analysis showed that sulfonamides tetracyclines, fluoroquinolones, and aminoglycosides have $12.64 \%, 14.01 \%$, $13.46 \%$, and $36.54 \%$ antibiotic concentration respectively (Molina et al., 2003). The concentration of various antibiotic residues in different foods are shown in Table 1.

\section{Toxic effects of antibiotics residues in food}

Antibiotics residues produce many toxic effects; however, the most common manifestation of various drugs is allergic reactions. These hypersensitivity reactions are observed in the case of tetracyclines, penicillin, and aminoglycosides (Katz and Brady, 2000). The effects caused by the long-term use of antibiotics on human health are still unknown. Furthermore, it is observed that $\beta$-lactams have few toxic effects on human health, these are mainly involved in eliciting allergic reactions (Davies and Davies, 2010). For instance, it has been reported that tetracycline causes several peculiar reactions like allergy, phototoxic dermatitis, and skin rashes (Yates and deShazo, 2003). Among the individuals sensitive to the penicillins group, the residues of penicillin in milk resulted in allergic reactions (Dewdney et al., 1991; Demoly and Romano, 2005). Another drug streptomycin has significant side effects, for example, it affects vestibular mechanisms in the inner ear which causes the loss of balance, neurotoxic effects on newborns, fever, and skin rashes. The allergic response to the macrolides metabolites modified by the hepatic cells can cause liver injury (Dewdney et al., 1991). Residues of chloramphenicol in foods can cause fatal blood dyscrasia in individuals (Settepani, 1984).

\section{Carcinogenic effects}

Carcinogenic residues bind covalently to several intracellular components, for example, glycogen, glutathione, deoxyribonucleic acid (DNA), ribonucleic acid (RNA), proteins, and phospholipids, and show latent hazards (Beyene, 2016). It has been reported that Chloramphenicol residues present in food causes cancer (Demoly and Romano, 2005, Nisha, 2008). 
Table 1. Detection methods for the determination of concentrations of antibiotic residues in different food items

\begin{tabular}{|c|c|c|c|c|c|}
\hline $\begin{array}{c}\text { Detection } \\
\text { Method }\end{array}$ & $\begin{array}{c}\text { Sample } \\
\text { Type }\end{array}$ & \begin{tabular}{|c|} 
Number of \\
samples
\end{tabular} & $\begin{array}{c}\text { Antimicrobial } \\
\text { Agents }\end{array}$ & $\begin{array}{l}\text { Concentrations } \\
(\mu \mathrm{g} / \mathrm{L} \text { or } \mu \mathrm{g} / \mathrm{kg})\end{array}$ & Reference \\
\hline \multirow{4}{*}{$\begin{array}{c}\text { LC-qTOF- } \\
\text { MS }\end{array}$} & Fish & 53 & Multiple & $6.9-148.4$ & \multirow{4}{*}{$\begin{array}{c}\text { (Wang et al., } \\
\text { 2017b) }\end{array}$} \\
\hline & Chicken & 18 & Multiple & $0.1-49.6$ & \\
\hline & Pork & 17 & Multiple & $0.3-27.0$ & \\
\hline & Shrimp & 18 & Multiple & $0.4-66.9$ & \\
\hline \multirow{24}{*}{$\begin{array}{c}\text { LC- } \\
\text { MS/MS }\end{array}$} & Milk (Cow) & 22 & Fluoroquinolones & $0.34-333$ & (Tang et al., \\
\hline & Raw milk (Fresh) & 25 & Sulfapyridine & 1.77 & (Han et al., \\
\hline & Fish (market) & 9 & Oxytetracycline & Upto 60 & (Cháfer-Pericás \\
\hline & Fish (farmed) & 20 & Oxytetracycline & 59 & $\begin{array}{l}\text { (Cháfer-Pericás } \\
\text { et al., 2011) }\end{array}$ \\
\hline & Fish (fresh water) & 443 & Aminoglycosides & $5-125$ & $\begin{array}{c}\text { (Gbylik-Sikorska } \\
\text { et al., 2014) }\end{array}$ \\
\hline & Fish (freshwater) & 13 & Multiple & $0.4-38.5$ & $\begin{array}{l}\text { (Wei et al., } \\
\text { 2014) }\end{array}$ \\
\hline & Fish (freshwater) & 128 & Erythromycin & 2390 & $\begin{array}{c}\text { (Zhao et al., } \\
\text { 2015) }\end{array}$ \\
\hline & Fish (farmed) & 75 & Norfloxacin & 15 & $\begin{array}{l}\text { (Yipel et al., } \\
\text { 2017) }\end{array}$ \\
\hline & Fish (farmed) & 193 & Enrofloxacin & $>50$ & $\begin{array}{l}\text { (Guidi et al., } \\
\text { 2017) }\end{array}$ \\
\hline & Fish & 116 & Sulfonamides & Upto 1634 & $\begin{array}{l}\text { (Song et al., } \\
\text { 2017a) }\end{array}$ \\
\hline & Fish & 116 & Fluoroquinolones & Upto 47108 & $\begin{array}{c}\text { (Song et al., } \\
2017 \mathrm{~b})\end{array}$ \\
\hline & Fish & 31 & Enrofloxacin & Up to 2200 & $\begin{array}{c}\text { (Chen et al., } \\
\text { 2018) }\end{array}$ \\
\hline & Wild fish (Marine) & 21 & Multiple & $22-500$ & (Liu et al., 2018) \\
\hline & Pork & 10 & $\begin{array}{l}\text { Ampicillin } \\
\text { ceftiofur }\end{array}$ & $\begin{array}{c}20 \\
400\end{array}$ & $\begin{array}{c}\text { (Huang et al., } \\
\text { 2016) }\end{array}$ \\
\hline & Chicken & 156 & Sulfonamide & $2500-2700$ & $\begin{array}{c}\text { (Yamaguchi et } \\
\text { al., 2015) }\end{array}$ \\
\hline & Meat (Pork) & 100 & sulfamethazine & $11-1600$ & $\begin{array}{c}\text { (Ngoc Do et al., } \\
2016)\end{array}$ \\
\hline & Eggs & 22 & Multiple & Up to 30.3 & $\begin{array}{l}\text { (Wang et al., } \\
\text { 2017a) }\end{array}$ \\
\hline & Eggs & 111 & enrofloxacin & $1.7-1485$ & $\begin{array}{l}\text { (Yamaguchi et } \\
\text { al., 2017) }\end{array}$ \\
\hline & Vegetables & 4 & Chlortetracycline & $0.1-532$ & (Hu et al., 2010) \\
\hline & Vegetable Crops & 5 & Multiple & Up to 46.4 & (Hu et al., 2010) \\
\hline & Leafy Vegetables & 15 & Tetracycline & Up to 8.84 & (Yu et al., 2018) \\
\hline & Fish and Meat (Raw) & 18 & Erythromycin & $58-87$ & $\begin{array}{c}\text { (Berrada et al., } \\
\text { 2008) }\end{array}$ \\
\hline & Pork & 51 & $\begin{array}{l}\text { sulfacetamide } \\
\text { sulfaguinoxaline }\end{array}$ & 1.2 & \\
\hline & Egg & 51 & $\begin{array}{l}\text { suraquinoxacine } \\
\text { Saraflox }\end{array}$ & $\begin{array}{c}3.3 \\
0.98\end{array}$ & (He et al., 2017) \\
\hline \multirow[t]{4}{*}{ EIA } & Fish & 20 & Oxytetracycline & $2.1-152$ & (Cháfer-Pericás \\
\hline & Chicken & 127 & Quinolones & 30.8 (mean va & (Er et al., 2013) \\
\hline & Beef & 104 & Quinolones & 6.64 (mean value) & (Er et al., 2013) \\
\hline & $\begin{array}{c}\text { Raw meat (chicken, } \\
\text { beef, and pork) }\end{array}$ & 150 & sulfanilamide & $14.2-1280$ & \begin{tabular}{|c} 
(Ramatla et al., \\
2017)
\end{tabular} \\
\hline
\end{tabular}




\begin{tabular}{|c|c|c|c|c|c|}
\hline $\begin{array}{c}\text { Detection } \\
\text { Method } \\
\end{array}$ & $\begin{array}{c}\text { Sample } \\
\text { Type }\end{array}$ & \begin{tabular}{|c|c}
$\begin{array}{c}\text { Number of } \\
\text { samples }\end{array}$ \\
\end{tabular} & $\begin{array}{c}\text { Antimicrobial } \\
\text { Agents }\end{array}$ & $\begin{array}{l}\text { Concentrations } \\
(\mu \mathrm{g} / \mathrm{L} \text { or } \mu \mathrm{g} / \mathrm{kg}) \\
\end{array}$ & Reference \\
\hline \multirow{7}{*}{$\begin{array}{c}\text { SNAP® } \\
\text { Test } \\
\text { HPLC }\end{array}$} & Vegetables & 11 & Multiple & $<10$ & $\begin{array}{c}\text { (Kang et al., } \\
\text { 2013) }\end{array}$ \\
\hline & Raw milk (fresh) & 199 & Sulfonamides & $<16.3$ & $\begin{array}{c}\text { (Zheng et al., } \\
\text { 2013) }\end{array}$ \\
\hline & Milk (cow and goat) & 269 & sulfamerazine & 12.2 & $\begin{array}{c}\text { (Chung et al., } \\
\text { 2009) }\end{array}$ \\
\hline & Milk & 328 & Penicillin-G & 15.2 (mean value) & $\begin{array}{c}\text { (Olatoye et al., } \\
\text { 2016) }\end{array}$ \\
\hline & Milk & 140 & $\begin{array}{l}\text { Ampicillin } \\
\text { Amoxicillin }\end{array}$ & $\begin{array}{c}0.5 \\
802\end{array}$ & $\begin{array}{c}\text { (Khanal et al., } \\
\text { 2018) }\end{array}$ \\
\hline & Raw meat (chicken & & $\begin{array}{l}\text { Sulphanilamide } \\
\text { Tetracycline }\end{array}$ & $\begin{array}{c}20.7-82.1 \\
41.8-320.8\end{array}$ & (Ramatla et al \\
\hline & beef, and pork) & 150 & $\begin{array}{l}\text { Streptomycin } \\
\text { Ciprofloxacin }\end{array}$ & $\begin{array}{c}65.2-952.2 \\
32.8-95.6\end{array}$ & 2017) \\
\hline
\end{tabular}

\section{Disruption of the normal flora}

Different bacteria that are part of our normal flora act as a bridge to prevent the entry of pathogens and causing diseases. Antibiotics may kill few important species and will decrease the number of bacteria, for example, broad-spectrum antibiotics such as streptomycin, tylosin, and flunixin in animals while metronidazole, vancomycin, and nitroimidazole in humans affect gastrointestinal diseases and disruption of normal flora (Cotter et al., 2012). The study has shown that the antibiotic residues present in the milk may alter the drug resistance status of the gut microflora during long-term exposure (Chand et al., 2000). Another study has reported the induction of antimicrobial resistance in human intestinal flora after the intake of meat products containing antibiotic residues that resulted in an outbreak of diarrhea (Landers et al., 2012). The intake of these residues entering enter the intestinal tract of humans interacts with nearly 800-1000 bacterial species and approximately 7000 different strains (Jernberg et al., 2010). Although 95\% of these bacterial species are beneficial for humans, the remaining bacterial species are opportunistic and can be harmful (Ben et al., 2019). In the human intestinal tract, a microecological balance is maintained between bacteria themselves and the bacteria and the human body, with a predominance of Firmicutes and Bacteroidetes, and a lesser number of Proteobacteria, Actinobacteria, Verrucomicrobia, and many other phyla some of which have not even identified or isolated (Arumugam et al., 2011). Various studies have highlighted the fact that exposure to antimicrobial agents is associated with significant changes in the intestinal microbial population and composition. This effect have a broader spectrum on the microbiota community rather targetting any particular bacterial species (Blaser, 2016). This is quite evident that the antimicrobial therapies resulted in compositional changes of gut microflora with an increasing number of Firmicutes and a reduction in Bacteroidetes. Further, these therapies also resulted in the emergence of antimicrobial-resistant bacterial strains which might be able to persist in the gastrointestinal tract for years (Jernberg et al., 2010; Andersson and Hughes, 2011; Pérez-Cobas et al., 2013). The subsequent imbalance of intestinal microflora may lead to the proliferation of opportunistic pathogens and different diseases for example pseudomembranous colitis, colorectal cancer, and other intestinal disorders (Damman et al., 2012). This scenario can be even worse in case these opportunistic bacteria develop 
multiple antibiotic resistance and evolve into superbugs, which can be a significant risk to individuals as well as wider society.

\section{Teratogenic effect}

Any chemical agent or drug that produces a harmful effect on a fetus or embryo during gestation is termed a teratogen. As a result, congenital disorders that influence functional, as well as structural integrity, take place (Beyene, 2016). For example, when benzimidazole and anthelmintic are administered at an early stage of pregnancy they produce toxic effects on the embryo, furthermore, the drug of oxfendazole i.e. benzimidazole has a mutagenic effect. Enrofloxacin; a fluoroquinolone antibiotic that inhibits the bacteria by targeting the DNA gyrase has shown to be teratogenic for the embryos of rabbits and rats (Guzmán et al., 2003).

\section{Reducing antibiotic residues for safer animal food products}

The appropriate use of the drug in veterinary settings results in healthy animal food. However, the higher level of antibiotic residues in the food can adversely affect human health. Multiple animal-related factors including age, breed, body condition and sex, various drug-related factors like dosage of the drug, type of drug formation, and route of administration have possible effects on the pharmacokinetics as well as antibiotic residue levels in meat, eggs, milk, and other edible tissues (Moreno and Lanusse, 2017). The concentration of drug residue in tissues depends upon its several physicochemical properties which play a key role in the regulation of drugs via cell membranes, for example, lipid solubility and acidic or basic properties of drugs. Drugs with highly lipidsolubility enter the extra and intracellular tissue compartments efficiently through passive diffusion, however poorly lipid-soluble drugs remain extracellularly (Lees and Toutain, 2012). It has been observed when drugs are administered through animal ears it helps to prevent the accumulation of drugs in edible animal tissues. Furthermore, various animal products are not consumed raw and the thermal processes such as boiling, sterilization, frying, steaming, pasteurization, evaporation, co-distillation, and roasting can lead to the loss or decrease in the drug residues (Đorđević and Đurović-Pejčev, 2016). Other processes can also help to reduce the drug residues in food products such as storage time, different $\mathrm{pH}$ levels, and fermentation.

\section{Reducing antibiotic residues in milk and milk products}

Residues of the veterinary drug in milk are an important concern to the consumers, processors, farmers, and milk regulatory agencies as milk or milk products are commonly used by everyone (Shaker and Elsharkawy, 2015). Before consumption, animal products go through vigorous heat treatment that causes protein denaturation, water loss, changed $\mathrm{pH}$, and fat degradation which helps to alter chemical structures, the quantity of drug residue, toxic well as the pharmacological effects (Hsieh et al., 2011). For example, it has been reported that heating milk by sterilization, pasteurization or ultra-heat treatment (UHT) helps to reduce drug residues in the milk. It was observed that the concentration of tetracycline decreased by $30 \%$ whereas the concentration of oxytetracycline decreased by $40 \%$ by using the ultra-heat treatment, furthermore, the concentration of tetracycline is reduced by $98 \%$ using the sterilization process. Macrolides residues can be reduced by 
up to $93 \%$ by heat therapy (Zorraquino et al., 2011). During yogurt production through heat treatment, lactic acid helps in the degradation of nafcillin, oxacillin, dicloxacillin and cloxacillin slightly, while precipitated proteins help to decrease residues of penicillin (Grunwald and Petz, 2003). Furthermore, concentrations of trichlorfon, dimethoate, and fenthion were reduced when two starter cultures were added during yogurt preparation (Regueiro et al., 2015). However, a total of 62 antimicrobial agents were tested for heat stability at $56^{\circ} \mathrm{C}(30$ minutes $)$ and $121^{\circ} \mathrm{C}(15$ minutes $)$ and was found that the aztreonam, azlocillin, oxacillin, and mezlocillin were remarkably heat-stable (Traub and Leonhard, 1995).

\section{Reducing antibiotic residues in eggs}

When drugs are given to laying hens, their metabolic products are stored as residues in the components of the egg i.e. albumin and yolk. Raw eggs are generally used after heat treatment and refrigeration. Heat therapy promotes protein denaturation, dehydration, and $\mathrm{pH}$ changes that help to decrease chemical formulation, residue quantity, and modify the solubility of residue. As a result, the concentration of tetracycline residues decreased by $52 \%$ and $47 \%$, whereas the concentration of enrofloxacin decreased by $69 \%$ and 58\% after boiling and frying eggs respectively (Ezenduka et al., 2011). However, when eggs were boiled at $100^{\circ} \mathrm{C}$ for 15 minutes the antibiotic residues i.e. concentration of chlortetracycline was reduced by $61 \%$, ciprofloxacin by $87 \%$, and enrofloxacin by $93 \%$, while other residues such as chlortetracycline by $20-22 \%$, and sulfanilamide by $44-49 \%$ were reduced when eggs were refrigerated at $10{ }^{\circ} \mathrm{C}$ for 4 weeks (Alaboudi et al., 2013). It was observed that the number of aflatoxin residues was significantly reduced after incorporation of Bacillus subtilis biodegradation preparations in the poultry diet which resulted in the biotransformation of toxin and inhibition of intestinal absorption of toxin and consequent reduction of toxin residues in the eggs (Jia et al., 2016).

\section{Reduction of drug residues in meat}

Inadequate biosafety methods and improper veterinary drugs may cause a decrease in the quality of meat and the accumulation of drug residues in meat. Several thermal treatments or cooking are essential before the consumption of animal food products. For this purpose, several methods such as fat loss, denaturation of proteins, altered $\mathrm{pH}$, and water loss have been used that aids in modifying the chemical structure, solubility, and concentration of drug residues. It has been observed that after cooking the meat, the concentration of doxycycline was reduced (Javadi, 2011), and changing the $\mathrm{pH}$ levels significantly decreased the level of oxytetracycline. For example, oxytetracycline's muscle concentration decreased approximately $53.6 \%$ after roasting and $69.6 \%$ after boiling, and after changing $\mathrm{pH}$, oxytetracycline reduced up to $67.7 \%, 53.2 \%$, and $34.3 \%$ following boiling, microwaving, and roasting (Vivienne et al., 2018). Furthermore, when pork and chicken are degraded with various heat treatments it significantly reduced oxytetracycline concentration. Furthermore, it has been observed that the concentration of sulfonamide residues decreased up to 38-40\% after roasting and 38-40\% after boiling in chicken meat (Furusawa and Hanabusa, 2002). 


\section{Management of antimicrobial residues; a food safety perspective}

The recommendations by various international organizations have insisted on the wiser use of antimicrobial agents in clinical, veterinary, and agriculture to protect public health. The world health organization (WHO) recommended that the national authorities for agriculture, veterinary, pharmaceuticals, and other stakeholders should focus to disregard the use of antimicrobial agents as growth promoters. Moreover, the antibiotics should be administered among the food animals only when the use is justified and prescribed by the veterinarian especially the third and fourth generation cephalosporins and fluoroquinolones (Economou and Gousia, 2015).

Animal health must be improved to decrease the requirement of antibiotics in food animals through biosafety and biosecurity measures and disease prevention by effective vaccination, use of probiotics, and good hygiene practices. The use of antibiotics must be for therapeutic purposes rather than growth promotion based on bacterial cultures and antibiotic susceptibility testing and clinical experience. The first choice should be narrowspectrum antibiotics while choosing antimicrobial agents. Further, the veterinarian professional bodies should establish guidelines on a national level for the proper usage of antibiotics among different food animals, by indicating the first, second, and last choices for the management of bacterial infections. Moreover, the economic incentives favoring the inapt prescription of antimicrobial agents should be abolished (Economou and Gousia, 2015; Norris et al., 2019).

An effective surveillance system for antibiotic resistance among commensal and zoonotic bacteria, as well as the bacteria obtained from different foods and food animal reservoirs, is essential to understand the emergence of antibiotic resistance and provide the data for risk assessment and implementation of targeted interventions. The comprehensive surveillance system includes the collection of data followed by analysis and reporting to monitor the temporal trends for the usage of antibiotics in people and food animals and to monitor antibiotic resistance among the bacteria isolated from humans, veterinary and foods (Ferri et al., 2017).

\section{Conclusions}

Although the specific regulations are limited due to the lack of consensus on the safer concentrations of antibiotic residues in the environment concerning the development of resistance, The WHO emphasizes the policies for the improvement of pharmaceutical waste management and to minimize the antibiotic residues in the environment. Despite the new medicines in the USA and Europe need environmental risk assessments by considering the ecological impacts of drugs, the medicines already available in the market have not undergone these valuations. These assessments do not address the potential of the drug in resistance implications, rather emphasize the ecological toxicity. The extensive use of antibiotics in animal feed for growth promotion poses a significant threat to public health due to its impact on the development of multidrug-resistant bacterial strains. The stringent control must be adapted to avoid the excessive use of these agents accompanied by the development of alternative measures to safeguard human health and to keep the available antibiotics effective for future clinical implications.

The continuous surveillance of antimicrobial resistance in the human, zoonotic and environmental bacteria is a precondition to understanding this phenomenon that can provide risk assessment data for the evaluation and implementation of targeted interventions. Awareness and communication at national and international levels are 
necessary for the rational use of antimicrobials in the food chains. These relevant target audiences must be identified including the decision-makers, agriculture, health and veterinary professionals, media, and the public, and should be informed with evidencebased information for their guidance, decisions, and choices. The knowledge gaps still exist in the precise understanding of antibiotic resistance and its implications in food safety. The studies must focus on the quantitative analysis of the disease burden caused by resistant bacteria. These studies will further contribute to assessing the magnitude of the problem and will assist in the risk assessment the designing cost-effective protocols to counteract this menace.

Funding. This research received no external funding.

Conflicts of Interests. The authors declare no conflict of interests.

\section{REFERENCES}

[1] Aarestrup, F. M., Bager, F., Jensen, N. E., Madsen, M., Meyling, A., Wegener, H. C. (1998): Surveillance of antimicrobial resistance in bacteria isolated from food animals to antimicrobial growth promoters and related therapeutic agents in Denmark. - APMIS 106: 606-622.

[2] Akici, A., Aydin, V., Kiroglu, A. (2018): Assessment of the association between drug disposal practices and drug use and storage behaviors. - Saudi Pharmaceutical Journal 26: 7-13.

[3] Alaboudi, A., Basha, E. A., Musallam, I. (2013): Chlortetracycline and sulfanilamide residues in table eggs: Prevalence, distribution between yolk and white and effect of refrigeration and heat treatment. - Food Control 33: 281-286.

[4] Andersson, D. I., Hughes, D. (2011): Persistence of antibiotic resistance in bacterial populations. - FEMS Microbiology Reviews 35: 901-911.

[5] Ao, X., Liu, W., Sun, W., Cai, M., Ye, Z., Yang, C., Lu, Z., Li, C. (2018): Medium pressure UV-activated peroxymonosulfate for ciprofloxacin degradation: Kinetics, mechanism, and genotoxicity. - Chemical Engineering Journal 345: 87-97.

[6] Arumugam, M., Raes, J., Pelletier, E., Le Paslier, D., Yamada, T., Mende, D. R., Fernandes, G. R., Tap, J., Bruls, T., Batto, J.-M., Bertalan, M., Borruel, N., Casellas, F., Fernandez, L., Gautier, L., Hansen, T., Hattori, M., Hayashi, T., Kleerebezem, M., Kurokawa, K., Leclerc, M., Levenez, F., Manichanh, C., Nielsen, H. B., Nielsen, T., Pons, N., Poulain, J., Qin, J., Sicheritz-Ponten, T., Tims, S., Torrents, D., Ugarte, E., Zoetendal, E. G., Wang, J., Guarner, F., Pedersen, O., De Vos, W. M., Brunak, S., Doré, J., Antolín, M., Artiguenave, F., Blottiere, H. M., Almeida, M., Brechot, C., Cara, C., Chervaux, C., Cultrone, A., Delorme, C., Denariaz, G., Dervyn, R., Foerstner, K. U., Friss, C., Van De Guchte, M., Guedon, E., Haimet, F., Huber, W., Van Hylckama-Vlieg, J., Jamet, A., Juste, C., Kaci, G., Knol, J., Kristiansen, K., Lakhdari, O., Layec, S., Le Roux, K., Maguin, E., Mérieux, A., Melo Minardi, R., M'rini, C., Muller, J., Oozeer, R., Parkhill, J., Renault, P., Rescigno, M., Sanchez, N., Sunagawa, S., Torrejon, A., Turner, K., Vandemeulebrouck, G., Varela, E., Winogradsky, Y., Zeller, G., Weissenbach, J., Ehrlich, S. D., Bork, P., Meta, H. I. T. C. (2011): Enterotypes of the human gut microbiome. - Nature 473: 174-180.

[7] Azanu, D., Mortey, C., Darko, G., Weisser, J. J., Styrishave, B., Abaidoo, R. C. (2016): Uptake of antibiotics from irrigation water by plants. - Chemosphere 157: 107-114.

[8] Barton, M. D. (2000): Antibiotic use in animal feed and its impact on human health. Nutrition Research Reviews 13: 279-299. 
[9] Bassil, R. J., Bashour, I., Sleiman, F. T., Abou-Jawdeh, Y. A. (2013): Antibiotic uptake by plants from manure-amended soils. - Journal of Environmental Science and Health, Part B 48: 570-574.

[10] Ben, Y., Fu, C., Hu, M., Liu, L., Wong, M. H., Zheng, C. (2019): Human health risk assessment of antibiotic resistance associated with antibiotic residues in the environment: a review. - Environmental Research 169: 483-493.

[11] Berrada, H., Borrull, F., Font, G., Marcé, R. M. (2008): Determination of macrolide antibiotics in meat and fish using pressurized liquid extraction and liquid chromatographymass spectrometry. - Journal of Chromatography A 1208: 83-89.

[12] Beyene, T. (2016): Veterinary drug residues in food-animal products: its risk factors and potential effects on public health. - Journal of Veterinary Science \& Technology 7: 1-7.

[13] Blaser, M. J. (2016): Antibiotic use and its consequences for the normal microbiome. Science 352: 544-545.

[14] Brown, K. D., Kulis, J., Thomson, B., Chapman, T. H., Mawhinney, D. B. (2006): Occurrence of antibiotics in hospital, residential, and dairy effluent, municipal wastewater, and the Rio Grande in New Mexico. - Science of the Total Environment 366: 772-783.

[15] Catteau, L., Zhu, L., Van Bambeke, F., Quetin-Leclercq, J. (2018): Natural and hemisynthetic pentacyclic triterpenes as antimicrobials and resistance modifying agents against Staphylococcus aureus: a review. - Phytochemistry Reviews 17(5): 1129-1163.

[16] Cháfer-Pericás, C., Maquieira, Á., Puchades, R. (2010a): Fast screening methods to detect antibiotic residues in food samples. - TrAC Trends in Analytical Chemistry 29: 1038-1049.

[17] Cháfer-Pericás, C., Maquieira, Á., Puchades, R., Company, B., Miralles, J., Moreno, A. (2010b): Multiresidue determination of antibiotics in aquaculture fish samples by HPLCMS/MS. - Aquaculture Research 41: e217-e225.

[18] Cháfer-Pericás, C., Maquieira, Á., Puchades, R., Miralles, J., Moreno, A. (2011): Multiresidue determination of antibiotics in feed and fish samples for food safety evaluation. Comparison of immunoassay vs LC-MS-MS. - Food Control 22: 993-999.

[19] Chand, R., Bhavadasan, M., Vijaya, G. (2000): Antibiotic residues in milk. - Indian Journal of Dairy and Biosciences 11: 151-154.

[20] Chattopadhyay, M. K. (2014): Use of antibiotics as feed additives: a burning question. Frontiers in Microbiology 5: 334.

[21] Chen, H., Liu, S., Xu, X. R., Diao, Z. H., Sun, K. F., Hao, Q. W., Liu, S. S., Ying, G. G. (2018): Tissue distribution, bioaccumulation characteristics and health risk of antibiotics in cultured fish from a typical aquaculture area. - Journal of Hazardous Materials 343: 140148.

[22] Chowdhury, S., Hassan, M. M., Alam, M., Sattar, S., Bari, M. S., Saifuddin, A. K., Hoque, M. A. (2015): Antibiotic residues in milk and eggs of commercial and local farms at Chittagong, Bangladesh. - Veterinary World 8: 467-471.

[23] Chung, H.-H., Lee, J.-B., Chung, Y.-H., Lee, K.-G. (2009): Analysis of sulfonamide and quinolone antibiotic residues in Korean milk using microbial assays and high performance liquid chromatography. - Food Chemistry 113: 297-301.

[24] Cotter, P. D., Stanton, C., Ross, R. P., Hill, C. (2012): The impact of antibiotics on the gut microbiota as revealed by high throughput DNA sequencing. - Discovery Medicine 13: 193-199.

[25] Cowieson, A. J., Kluenter, A. M. (2019): Contribution of exogenous enzymes to potentiate the removal of antibiotic growth promoters in poultry production. - Animal Feed Science and Technology 250: 81-92.

[26] Damman, C. J., Miller, S. I., Surawicz, C. M., Zisman, T. L. (2012): The microbiome and inflammatory bowel disease: is there a therapeutic role for fecal microbiota transplantation? - The American Journal of Gastroenterology 107: 1452-1459.

[27] Darwish, W. S., Eldaly, E. A., El-Abbasy, M. T., Ikenaka, Y., Nakayama, S., Ishizuka, M. (2013): Antibiotic residues in food: the African scenario. - The Japanese Journal of Veterinary Research 61 Suppl: S13-22. 
[28] Davies, J., Davies, D. (2010): Origins and evolution of antibiotic resistance. Microbiology and Molecular Biology Reviews 74: 417-433.

[29] Demoly, P., Romano, A. (2005): Update on beta-lactam allergy diagnosis. - Current Allergy and Asthma Reports 5: 9-14.

[30] Dewdney, J. M., Maes, L., Raynaud, J. P., Blanc, F., Scheid, J. P., Jackson, T., Lens, S., Verschueren, C. (1991): Risk assessment of antibiotic residues of beta-lactams and macrolides in food products with regard to their immuno-allergic potential. - Food and Chemical Toxicology 29: 477-483.

[31] Đorđević, T., Đurović-Pejčev, R. (2016): Food processing as a means for pesticide residue dissipation. - Pesticidi i Fitomedicina 31: 89-105.

[32] Economou, V., Gousia, P. (2015): Agriculture and food animals as a source of antimicrobial-resistant bacteria. - Infection and Drug Resistance 8: 49-61.

[33] Er, B., Onurdag, F. K., Demirhan, B., Ozgacar, S., Oktem, A. B., Abbasoglu, U. (2013): Screening of quinolone antibiotic residues in chicken meat and beef sold in the markets of Ankara, Turkey. - Poultry Science 92: 2212-2215.

[34] Esiobu, N., Armenta, L., Ike, J. (2002): Antibiotic resistance in soil and water environments. - International Journal of Environmental Health Research 12: 133-144.

[35] Ezenduka, E. V., Oboegbulem, S. I., Nwanta, J. A., Onunkwo, J. I. (2011): Prevalence of antimicrobial residues in raw table eggs from farms and retail outlets in Enugu State, Nigeria. - Tropical Animal Health and Production 43: 557-559.

[36] Ferri, M., Ranucci, E., Romagnoli, P., Giaccone, V. (2017): Antimicrobial resistance: A global emerging threat to public health systems. - Critical Reviews in Food Science and Nutrition 57: 2857-2876.

[37] Furusawa, N., Hanabusa, R. (2002): Cooking effects on sulfonamide residues in chicken thigh muscle. - Food Research International 35: 37-42.

[38] Gao, P., Munir, M., Xagoraraki, I. (2012): Correlation of tetracycline and sulfonamide antibiotics with corresponding resistance genes and resistant bacteria in a conventional municipal wastewater treatment plant. - Science of the Total Environment 421-422: 173183.

[39] Gbylik-Sikorska, M., Posyniak, A., Mitrowska, K., Gajda, A., Błądek, T., Śniegocki, T., Żmudzki, J. (2014): Occurrence of veterinary antibiotics and chemotherapeutics in fresh water, sediment, and fish of the rivers and lakes in Poland. - Bulletin of the Veterinary Institute in Pulawy 58: 399-404.

[40] Gonzalez Ronquillo, M., Angeles Hernandez, J. C. (2017): Antibiotic and synthetic growth promoters in animal diets: Review of impact and analytical methods. - Food Control 72: 255-267.

[41] Grenni, P., Ancona, V., Barra Caracciolo, A. (2018): Ecological effects of antibiotics on natural ecosystems: A review. - Microchemical Journal 136: 25-39.

[42] Grunwald, L., Petz, M. (2003): Food processing effects on residues: penicillins in milk and yoghurt. - Analytica Chimica Acta 483: 73-79.

[43] Guidi, L. R., Santos, F. A., Ribeiro, A. C., Fernandes, C., Silva, L. H., Gloria, M. B. (2017): A simple, fast and sensitive screening LC-ESI-MS/MS method for antibiotics in fish. Talanta 163: 85-93.

[44] Guzmán, A., García, C., Marín, A.-P., Willoughby, C., Demestre, I. (2003): Developmental toxicity studies of the quinolone antibacterial agent irloxacin in rats and rabbits. Arzneimittel-Forschung 53: 121-125.

[45] Haller, M. Y., Muller, S. R., Mcardell, C. S., Alder, A. C., Suter, M. J. (2002): Quantification of veterinary antibiotics (sulfonamides and trimethoprim) in animal manure by liquid chromatography-mass spectrometry. - Journal of Chromatography A 952: 111120.

[46] Han, R. W., Zheng, N., Yu, Z. N., Wang, J., Xu, X. M., Qu, X. Y., Li, S. L., Zhang, Y. D., Wang, J. Q. (2015): Simultaneous determination of 38 veterinary antibiotic residues in raw milk by UPLC-MS/MS. - Food Chemistry 181: 119-126. 
[47] He, J., Song, L., Zhou, G., Zhao, L. (2017): The Rapid Analysis of Antibiotics in Animal Meat and Egg Using a Novel SEP Method and UPLC-MS/MS. - Chromatographia 80: 1329-1342.

[48] Hillis, D. G., Lissemore, L., Sibley, P. K., Solomon, K. R. (2007): Effects of monensin on zooplankton communities in aquatic microcosms. - Environmental Science \& Technology 41: 6620-6626.

[49] Hong, B., Lin, Q., Yu, S., Chen, Y., Chen, Y., Chiang, P. (2018): Urbanization gradient of selected pharmaceuticals in surface water at a watershed scale. - Science of the Total Environment 634: 448-458.

[50] Hsieh, M.-K., Shyu, C.-L., Liao, J. W., Franje, C., Huang, Y. J., Chang, S. K., Shih, P. Y., Chou, C.-C. (2011): Correlation analysis of heat stability of veterinary antibiotics by structural degradation, changes in antimicrobial activity and genotoxicity. - Veterinarni Medicina 56: 274-285.

[51] Hu, X., Zhou, Q., Luo, Y. (2010): Occurrence and source analysis of typical veterinary antibiotics in manure, soil, vegetables and groundwater from organic vegetable bases, northern China. - Environmental Pollution 158: 2992-2998.

[52] Huang, Z., Pan, X.-D., Huang, B.-F., Xu, J.-J., Wang, M.-L., Ren, Y.-P. (2016): Determination of $15 \beta$-lactam antibiotics in pork muscle by matrix solid-phase dispersion extraction (MSPD) and ultra-high pressure liquid chromatography tandem mass spectrometry. - Food Control 66: 145-150.

[53] Ishikawa, N. K., Touno, E., Higashiyama, Y., Sasamoto, M., Soma, M., Yoshida, N., Ito, A., Umita, T. (2018): Determination of tylosin excretion from sheep to assess tylosin spread to agricultural fields by manure application. - Science of the Total Environment 633: 399404.

[54] Javadi, A. (2011): Effect of roasting, boiling and microwaving cooking method on doxycline residues in edible tissues of poultry by microbial method. - African Journal of Pharmacy and Pharmacology 5: 1034-1037.

[55] Jernberg, C., Löfmark, S., Edlund, C., Jansson, J. K. (2010): Long-term impacts of antibiotic exposure on the human intestinal microbiota. - Microbiology 156: 3216-3223.

[56] Jia, R., Ma, Q., Fan, Y., Ji, C., Zhang, J., Liu, T., Zhao, L. (2016): The toxic effects of combined aflatoxins and zearalenone in naturally contaminated diets on laying performance, egg quality and mycotoxins residues in eggs of layers and the protective effect of Bacillus subtilis biodegradation product. - Food and Chemical Toxicology 90: $142-150$.

[57] Kang, D. H., Gupta, S., Rosen, C., Fritz, V., Singh, A., Chander, Y., Murray, H., Rohwer, C. (2013): Antibiotic uptake by vegetable crops from manure-applied soils. - Journal of Agricultural and Food Chemistry 61: 9992-10001.

[58] Katz, S. E., Brady, M. S. (2000): Antibiotic residues in food and their significance. - Food Biotechnology 14: 147-171.

[59] Khanal, B. K. S., Sadiq, M. B., Singh, M., Anal, A. K. (2018): Screening of antibiotic residues in fresh milk of Kathmandu Valley, Nepal. - Journal of Environmental Science and Health, Part B 53: 57-86.

[60] Kirchhelle, C. (2018): Pharming animals: a global history of antibiotics in food production (1935-2017). - Palgrave Communications 4: 96.

[61] Krzeminski, P., Tomei, M. C., Karaolia, P., Langenhoff, A., Almeida, C. M. R., Felis, E., Gritten, F., Andersen, H. R., Fernandes, T., Manaia, C. M., Rizzo, L., Fatta-Kassinos, D. (2019): Performance of secondary wastewater treatment methods for the removal of contaminants of emerging concern implicated in crop uptake and antibiotic resistance spread: A review. - Science of The Total Environment 648: 1052-1081.

[62] Kumar, M., Jaiswal, S., Sodhi, K. K., Shree, P., Singh, D. K., Agrawal, P. K., Shukla, P. (2019): Antibiotics bioremediation: Perspectives on its ecotoxicity and resistance. Environment International 124: 448-461. 
[63] Kummerer, K. (2009): Antibiotics in the aquatic environment--a review--part I. Chemosphere 75: 417-434.

[64] Landers, T. F., Cohen, B., Wittum, T. E., Larson, E. L. (2012): A review of antibiotic use in food animals: perspective, policy, and potential. - Public Health Reports 127: 4-22.

[65] Larsson, D. G. (2014): Antibiotics in the environment. - Upsala Journal of Medical Sciences 119: 108-112.

[66] Lees, P., Toutain, P. L. (2012): The role of pharmacokinetics in veterinary drug residues. - Drug Testing and Analysis 4 Suppl 1: 34-39.

[67] Liu, X., Steele, J. C., Meng, X. Z. (2017): Usage, residue, and human health risk of antibiotics in Chinese aquaculture: A review. - Environmental Pollution 223: 161-169.

[68] Liu, X., Lu, S., Guo, W., Xi, B., Wang, W. (2018): Antibiotics in the aquatic environments: A review of lakes, China. - Science of the Total Environment 627: 1195-1208.

[69] Manyi-Loh, C., Mamphweli, S., Meyer, E., Okoh, A. (2018): Antibiotic Use in Agriculture and Its Consequential Resistance in Environmental Sources: Potential Public Health Implications. - Molecules 23(4): 795.

[70] Meena, V., Dotaniya, M., Saha, J., Patra, A. (2015): Antibiotics and antibiotic resistant bacteria in wastewater: impact on environment, soil microbial activity and human health. - African Journal of Microbiology Research 9: 965-978.

[71] Mitchell, J. M., Griffiths, M. W., Mcewen, S. A., Mcnab, W. B., Yee, A. J. (1998): Antimicrobial drug residues in milk and meat: causes, concerns, prevalence, regulations, tests, and test performance. - Journal of Food Protection 61: 742-756.

[72] Molina, A., Molina, M. P., Althaus, R. L., Gallego, L. (2003): Residue persistence in sheep milk following antibiotic therapy. - Veterinary Journal 165: 84-89.

[73] Moreno, L., Lanusse, C. (2017): Veterinary Drug Residues in Meat-Related Edible Tissues. - In: Purslow, P. P. (ed.) New Aspects of Meat Quality. Chapter 23, Woodhead Publishing.

[74] Mutiyar, P. K., Mittal, A. K. (2014): Risk assessment of antibiotic residues in different water matrices in India: key issues and challenges. - Environmental Science and Pollution Research International 21: 7723-7736.

[75] Ngoc Do, M. H., Yamaguchi, T., Okihashi, M., Harada, K., Konishi, Y., Uchida, K., Bui, L. T., Nguyen, T. D., Phan, H. B., Bui, H. D. T., Nguyen, P. D., Kajimura, K., Kumeda, Y., Dang, C. V., Hirata, K., Yamamoto, Y. (2016): Screening of antibiotic residues in pork meat in Ho Chi Minh City, Vietnam, using a microbiological test kit and liquid chromatography/tandem mass spectrometry. - Food Control 69: 262-266.

[76] Nisha, A. R. (2008): Antibiotic Residues - A Global Health Hazard. - Veterinary World 1: 375-377.

[77] Nodler, K., Voutsa, D., Licha, T. (2014): Polar organic micropollutants in the coastal environment of different marine systems. - Marine Pollution Bulletin 85: 50-59.

[78] Norris, J. M., Zhuo, A., Govendir, M., Rowbotham, S. J., Labbate, M., Degeling, C., Gilbert, G. L., Dominey-Howes, D., Ward, M. P. (2019): Factors influencing the behaviour and perceptions of Australian veterinarians towards antibiotic use and antimicrobial resistance. - PLoS One 14: e0223534.

[79] Obayiuwana, A., Ogunjobi, A., Yang, M., Ibekwe, M. (2018): Characterization of Bacterial Communities and Their Antibiotic Resistance Profiles in Wastewaters Obtained from Pharmaceutical Facilities in Lagos and Ogun States, Nigeria. - International Journal of Environmental Research and Public Health 15(7): 1365.

[80] Okocha, R. C., Olatoye, I. O., Adedeji, O. B. (2018): Food safety impacts of antimicrobial use and their residues in aquaculture. - Public Health Reviews 39: 21.

[81] Olatoye, I. O., Daniel, O. F., Ishola, S. A. (2016): Screening of antibiotics and chemical analysis of penicillin residue in fresh milk and traditional dairy products in Oyo state, Nigeria. - Veterinary World 9: 948-954.

[82] Pérez-Cobas, A. E., Gosalbes, M. J., Friedrichs, A., Knecht, H., Artacho, A., Eismann, K., Otto, W., Rojo, D., Bargiela, R., Von Bergen, M., Neulinger, S. C., Däumer, C., Heinsen, F.-A., Latorre, A., Barbas, C., Seifert, J., Dos Santos, V. M., Ott, S. J., Ferrer, M., Moya, 
A. (2013): Gut microbiota disturbance during antibiotic therapy: a multi-omic approach. Gut 62: 1591-1601.

[83] Phillips, I., Casewell, M., Cox, T., De Groot, B., Friis, C., Jones, R., Nightingale, C., Preston, R., Waddell, J. (2004): Does the use of antibiotics in food animals pose a risk to human health? A critical review of published data. - J Antimicrob Chemother 53: 28-52.

[84] Piña, B., Bayona, J. M., Christou, A., Fatta-Kassinos, D., Guillon, E., Lambropoulou, D., Michael, C., Polesel, F., Sayen, S. (2018): On the contribution of reclaimed wastewater irrigation to the potential exposure of humans to antibiotics, antibiotic resistant bacteria and antibiotic resistance genes - NEREUS COST Action ES1403 position paper. - Journal of Environmental Chemical Engineering 8(1): 102131.

[85] Pruden, A., Larsson, D. G., Amézquita, A., Collignon, P., Brandt, K. K., Graham, D. W., Lazorchak, J. M., Suzuki, S., Silley, P., Snape, J. R., Topp, E., Zhang, T., Zhu, Y. G. (2013): Management options for reducing the release of antibiotics and antibiotic resistance genes to the environment. - Environmental Health Perspectives 121: 878-885.

[86] Ramatla, T., Ngoma, L., Adetunji, M., Mwanza, M. (2017): Evaluation of Antibiotic Residues in Raw Meat Using Different Analytical Methods. - Antibiotics (Basel) 6(4): 34.

[87] Regueiro, J., Lopez-Fernandez, O., Rial-Otero, R., Cancho-Grande, B., Simal-Gandara, J. (2015): A review on the fermentation of foods and the residues of pesticidesbiotransformation of pesticides and effects on fermentation and food quality. - Critical Reviews in Food Science and Nutrition 55: 839-863.

[88] Sarpong, E. M., Miller, G. E. (2015): Narrow- and Broad-Spectrum Antibiotic Use among U.S. Children. - Health Services Research 50: 830-846.

[89] Settepani, J. A. (1984): The hazard of using chloramphenicol in food animals. - Journal of the American Veterinary Medical Association 184: 930-931.

[90] Shaker, E. M., Elsharkawy, E. E. (2015): Organochlorine and organophosphorus pesticide residues in raw buffalo milk from agroindustrial areas in Assiut, Egypt. - Environmental Toxicology and Pharmacology 39: 433-440.

[91] Song, C., Li, L., Zhang, C., Kamira, B., Qiu, L., Fan, L., Wu, W., Meng, S., Hu, G., Chen, J. (2017a): Occurrence and human dietary assessment of sulfonamide antibiotics in cultured fish around Tai Lake, China. - Environmental Science and Pollution Research International 24: 17493-17499.

[92] Song, C., Zhang, C., Kamira, B., Qiu, L., Fan, L., Wu, W., Meng, S., Hu, G., Chen, J. (2017b): Occurrence and human dietary assessment of fluoroquinolones antibiotics in cultured fish around tai lake, China. - Environmental Toxicology and Chemistry 36: 28992905.

[93] Tang, Q., Yang, T., Tan, X., Luo, J. (2009): Simultaneous determination of fluoroquinolone antibiotic residues in milk sample by solid-phase extraction-liquid chromatography-tandem mass spectrometry. - Journal of Agricultural and Food Chemistry 57: 4535-4539.

[94] Tasho, R. P., Cho, J. Y. (2016): Veterinary antibiotics in animal waste, its distribution in soil and uptake by plants: A review. - Science of the Total Environment 563-564: 366-376.

[95] Tollefson, L., Miller, M. A. (2000): Antibiotic use in food animals: controlling the human health impact. - Journal of AOAC International 83: 245-254.

[96] Traub, W. H., Leonhard, B. (1995): Heat stability of the antimicrobial activity of sixty-two antibacterial agents. - J Antimicrob Chemother 35: 149-154.

[97] Van Boeckel, T. P., Brower, C., Gilbert, M., Grenfell, B. T., Levin, S. A., Robinson, T. P., Teillant, A., Laxminarayan, R. (2015): Global trends in antimicrobial use in food animals. - Proceedings of the National Academy of Sciences of the United States of America 112: 5649-5654.

[98] Vivienne, E. E., Josephine, O. O., Anaelom, N. J. (2018): Effect of temperature (cooking and freezing) on the concentration of oxytetracycline residue in experimentally induced birds. - Veterinary World 11: 167-171. 
[99] Wang, K., Lin, K., Huang, X., Chen, M. (2017a): A Simple and Fast Extraction Method for the Determination of Multiclass Antibiotics in Eggs Using LC-MS/MS. - Journal of Agricultural and Food Chemistry 65: 5064-5073.

[100] Wang, L., Yang, B., Zhang, X., Zheng, H. (2017b): Novel Two-Dimensional Liquid Chromatography-Tandem Mass Spectrometry for the Analysis of Twenty Antibiotics Residues in Dairy Products. - Food Analytical Methods 10: 2001-2010.

[101] Wei, Y., Zhang, Y., Xu, J., Guo, C., Li, L., Fan, W. (2014): Simultaneous quantification of several classes of antibiotics in water, sediments, and fish muscles by liquid chromatography-tandem mass spectrometry. - Frontiers of Environmental Science \& Engineering 8: 357-371.

[102] Witte, W. (1998): Medical consequences of antibiotic use in agriculture. - Science 279: 996-997.

[103] Yamaguchi, T., Okihashi, M., Harada, K., Konishi, Y., Uchida, K., Do, M. H., Bui, H. D., Nguyen, T. D., Nguyen, P. D., Chau, V. V., Dao, K. T., Nguyen, H. T., Kajimura, K., Kumeda, Y., Bui, C. T., Vien, M. Q., Le, N. H., Hirata, K., Yamamoto, Y. (2015): Antibiotic residue monitoring results for pork, chicken, and beef samples in Vietnam in 2012-2013. - Journal of Agricultural and Food Chemistry 63: 5141-5145.

[104] Yamaguchi, T., Okihashi, M., Harada, K., Konishi, Y., Uchida, K., Hoang Ngoc Do, M., Thi Bui, L., Nguyen, T. D., Phan, H. B., Dang Thien Bui, H., Nguyen, P. D., Kajimura, K., Kumeda, Y., Van Dang, C., Hirata, K., Yamamoto, Y. (2017): Detection of antibiotics in chicken eggs obtained from supermarkets in Ho Chi Minh City, Vietnam. - Journal of Environmental Science and Health, Part B 52: 430-433.

[105] Yates, A. B., Deshazo, R. D. (2003): Allergic and nonallergic drug reactions. - Southern Medical Journal 96: 1080-1087.

[106] Yelin, I., Kishony, R. (2018): Antibiotic Resistance. - Cell 172: 1136-1136.e1131.

[107] Yipel, M., Kürekci, C., Tekeli, İ. O., Metli, M., Sakin, F. (2017): Determination of selected antibiotics in farmed fish species using LC-MS/MS. - Aquaculture Research 48: 38293836.

[108] Yu, X., Liu, H., Pu, C., Chen, J., Sun, Y., Hu, L. (2018): Determination of multiple antibiotics in leafy vegetables using QuEChERS-UHPLC-MS/MS. - Journal of Separation Science 41: 713-722.

[109] Zhao, J. L., Liu, Y. S., Liu, W. R., Jiang, Y. X., Su, H. C., Zhang, Q. Q., Chen, X. W., Yang, Y. Y., Chen, J., Liu, S. S., Pan, C. G., Huang, G. Y., Ying, G. G. (2015): Tissuespecific bioaccumulation of human and veterinary antibiotics in bile, plasma, liver and muscle tissues of wild fish from a highly urbanized region. - Environmental Pollution 198: $15-24$.

[110] Zheng, N., Wang, J., Han, R., Xu, X., Zhen, Y., Qu, X., Sun, P., Li, S., Yu, Z. (2013): Occurrence of several main antibiotic residues in raw milk in 10 provinces of China. Food Additives \& Contaminants, Part B, Surveillance 6: 84-89.

[111] Zorraquino, M. A., Althaus, R. L., Roca, M., Molina, M. P. (2011): Heat treatment effects on the antimicrobial activity of macrolide and lincosamide antibiotics in milk. - Journal of Food Protection 74: 311-315. 